\title{
Developing Habitat Conservation Suitable For Nam Xouang Reservoir, Vientiane Province, Lao PDR
}

Dina Muthmainnah ${ }^{1,2, *}$, Aroef Hukmanan Rais ${ }^{1,2}$, Dongdavanh Sibouthong ${ }^{3}$

${ }^{1}$ Research Institute for Inland Fisheries and Extension,Ministry of Marine Affairs and Fisheries, Indonesia

${ }^{2}$ Inland Fishery Resources Development and Management Department (IFRDMD), Southeast Asian Fisheries Development Center (SEAFDEC)

${ }^{3}$ Division of Fisheries, Department of Livestock and Fisheries, Lao PDR

*Corresponding Author: dina.muthmainnah@kkp.go.id

\begin{tabular}{llll} 
Article history & & & \\
\hline Received & Received in revised form & Accepted & Available online \\
12 October 2018 & 1 August 2019 & 30 August 2019 & 31 August 2019 \\
\hline
\end{tabular}

\begin{abstract}
The establishment of the conservation area considers the most important issues of the environment changing in inland waters of ASEAN Countries. To respond this issue, a study was conducted in Nam Xouang Reservoir, Lao PDR, in 2018. To determine the conservation area, data and information were collected by mapping the deep waters area of spawning grounds, feeding ground, fishing seasons, and fish species caught. The data was collected with the support of six enumerators in upper-side and downside of the reservoir to identify the fish species and fish length-weight data. Results showed that built the display boards and warning signs is an effective way of considering simultaneously, to inform the local villagers about the fishing regulations and fish conservation zones. The participation of local fishing communities and local authorities might be necessary for the successful and sustainable management of the fisheries in the Nam Xouang Reservoir.
\end{abstract}

Keywords: conservation zone, fisheries management, Nam Xouang Reservoir, Lao PDR

Abstrak: Untuk menjaga perairan daratan dari perubahan lingkungan di Negara ASEAN, salah satu cara adalah dengan menetapkan kawasan konservasi. Menanggapi isu tersebut, sebuah penelitian dilakukan di Waduk Nam Xouang, Laos, pada 2018. Untuk menentukan kawasan konservasi, data dan informasi dikumpulkan dengan memetakan wilayah perairan dalam (daerah penangkapan ikan, daerah pemijahan, daerah mencari makan, musim penangkapan ikan, dan spesies ikan yang ditangkap). Data dikumpulkan di bagian atas dan bawah waduk dengan dukungan enam enumerator untuk mengidentifikasi spesies ikan dan data panjang-berat ikan. Hasil menunjukkan bahwa memasang papan dan rambu peringatan adalah cara yang efektif untuk menginformasikan kepada penduduk desa setempat tentang peraturan penangkapan ikan dan zona konservasi ikan. Partisipasi komunitas nelayan lokal dan otoritas lokal diperlukan untuk keberhasilan pengelolaan perikanan yang berkelanjutan di Waduk Nam Xouang.

Kata kunci: zona konservasi, Waduk Nam Xouang, pengelolaan perikanan, Lao PDR

\section{Introduction}

Lao People's Democratic Republic (Lao PDR) is a mountainous landlocked country, located in the Lower Mekong River Basin (LMB) in Southeast Asia. The $87.7 \%$ (or $207,674 \mathrm{~km}^{2}$ ) of the area are laying in the LMB, and the total area of water resources for capture fisheries is estimated more than 1.24 million hectares. Lao PDR is endowed with rich and abundant natural water resources as well as manmade water bodies, and more than 481 fish species identified in Lao PDR including 22 exotic species. These inland water resources have high potentials for the development of capture fisheries and aquaculture if properly managed and developed in a sustainable manner [1][2].

The Government of Lao PDR policies favor irrigation to support rice production, by developing many new constructions of irrigation reservoirs. Several larger reservoirs support hydropower or multiple uses, such as provide increased opportunities for fisheries and aquaculture. There are many reservoirs in Lao PDR, such as Nam Ngum Reservoir, Nam Houm Reservoir, Nam Hinboun Reservoir, Nam Ou Reservoir, Nam Song Reservoir, and Nam Xouang Reservoir.

The fisheries in reservoirs are increasingly important, and the Government authorities concerned that the communities directly depend on the fishing and aquaculture is fundamental to keep the sustainability biodiversity. It recognizes that reservoir fisheries management is an important component of rural development with their contribution to socioeconomic development in the country.

Nam Xouang Reservoir was built in 1981, located in the central part of northern Lao PDR with the main purpose to irrigate the rice field, and surface area at full supply level is 2,200 hectares (DLF Lao PDR Report). Fisheries activities generatea 
significant income, by providing a large proportion of the protein and nutrients and other dietary requirements for the people living in the surrounding. To support the fishery activities, the Government has already established the Fisheries Management Committee.

In the National Assembly No. 03/NA 2009 [3] regarding the Fisheries Law, mention in Part I, article 3 , the definition of Fish ConservationZone means deep water areas or along the rivers which are identified by fisheries management committee or according to fisheries regulations at village level, which designated as prohibited zone for the whole year to be habitats and safe breeding of aquatic organisms. The Government exhibits the concern on developing the habitat conservation for keeping the sustainability of fish resources, as well as should be environmentally friendly and enhance the economic wellbeing of the fishers.Therefore, this paper reported the activity of developing habitat conservation suitable for Nam Xouang Reservoir, Vientiane Province, Lao PDR.

\section{Material and Methods}

A current study was conducted in Nam Xouang Reservoir, Vientiane Province, Lao PDR along 2018. Data collection was done from two districts (Phonhong and Naxaythong Districts) (Figure 1). A technical assistance was provided by training the enumerators to collect the data and information. Sixenumerators were hired to observe the actual fish catch monitoring, by serving the daily data on weight-length, total catch, operational time and fishing gears used. Four enumerators were charged to collect the fisheries data and the others were focussed for collecting the fish biology data. One stopper also hired to input the data and to translate the data and information from the Lao language into English.

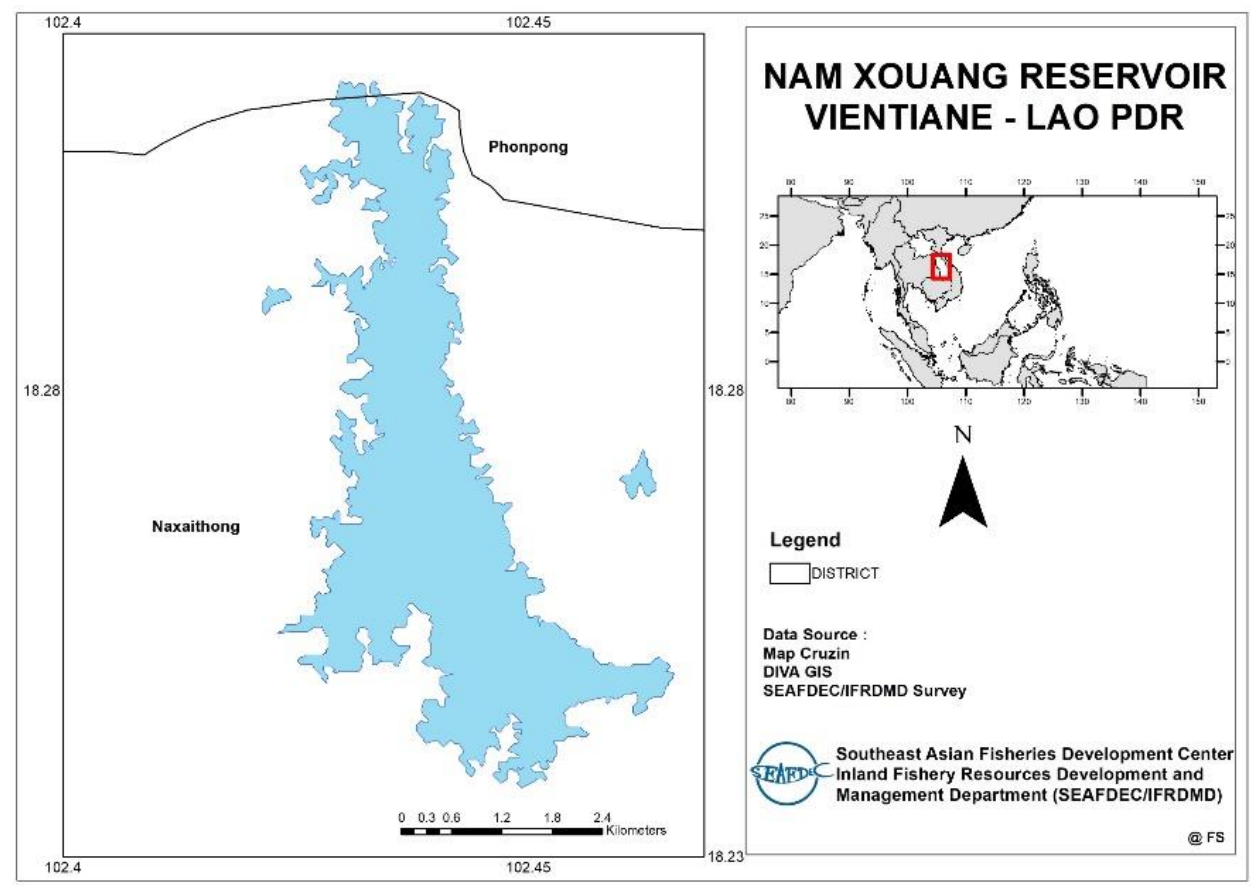

Figure 1. Research site

For monitoring the utilization of reservoir, local government established the Fisheries Management Committee (FMC). The person who involved as the management in FMC are the local fishers lived surrounding the reservoir. During the five surveys, the meeting was conducted by with local government and FMC in each district. The meeting was aimed at strengthening in managing and controlling the conservation areas. While holding the discussion, the information was gathered regarding the determination of demarcation of conservation area, improvement of the awareness to fisheries resources sustainability, requirement of data of fish identification, and accomplishment of the social impact after the conservation area construction.

The demarcated conservations were marked by installing the buoys and let the local fishers and residents to know about the conservation areas. The map was made by determining the spawning ground and feeding ground of fish. Those areas were declared as no-fishing zone, where the fishing is not allowed in the areas to enhance new recruitment of the fish stock.

There are several enhancement practices which together contribute to a process that can be termed the recruitment of stock and intensification of production [4]. These practices cover a range between culture-enhanced capture fisheries to 
intensive aquaculture. These are often adopted in a stepwise manner leading to a progressive increase in fishery production per unit area of water through increasing human controls on essential parameters of the fish assemblages, for instance 1) Stocking natural waters to improve recruitment, bias fish assemblage structure to favoured species or maintain productive species that would not breed naturally in the system; 2) Engineering of the environment to improve levels of reproduction, shelter, food resources and vital habitat; 3) Elimination of unwanted species that either compete with or predate upon target species; 4) Constituting an artificial fauna of selected species to increase the degree of control and the yield from the system; 5) Modification of water bodies to cut off an area to serve for extensive and intensive fish ponds to increase control and nutrient flows;

In this area, to further strengthen the enhancement of new recruitment of stock, the signboards of the conservation zone were distributed and installed containing the information on the importance and benefits of practicing conservation areas to the residents.

\section{Results and Discussion}

\subsection{Present status of inland fisheries in Nam Xouang Reservoir \\ Capture fisheries and aquaculture in Lao PDR} are based on water resource ecosystems mainly consisting of rivers and streams, hydropower and irrigation reservoirs, diversion weirs, small water bodies, flood plains and wet-season rice-fields. The estimate of actual fish consumption per capita ( $\mathrm{kg} / \mathrm{capita} /$ year) of inland fish is $24.5 \mathrm{~kg}$ [2]. The most fishing in Lao PDR is subsistence fishing activity as well as in Nam Xouang Reservoir, although there is significant commercial fishing in the Nam Ngum Reservoir [2]. The data of present status of Nam Xouang Reservoir is still lack, since this reservoir was built in 1981. The Nam Xouang Reservoir has a Fisheries Management Committee (FMC), that is situated in covering two areas in Vientiane Metropolis, and Vientiane Province. The two areas are Phonhong District and Naxaythong District that have 25 and $20 \mathrm{FMC}$, respectively. The main occupation of the communities is to work in the rice field and fisheries. The data of annual fish production was gathered by FMC from 2014 to 2017, and it can estimate the Catch per Unit Effort (CPUE) (Table 1). CPUE is a method used to determine the yield of fisheries production which is averaged in annual. Fisheries production in an area has increased, or decreased production can be known from the results of CPUE [5].

In this research, identifying the key issues of the fishery activities and fish biological data collection becomes important. A lack of information and statistical data on inland fisheries has undermined their importance and the subsequent management of the resources. With a growing population, it is necessary to maintain the contributions of inland fisheries to food security and to increase production. Prioritization of freshwater habitat management and conservation is dependent on the availability of species baseline information at the regional level [6].

Compared with 481 fish species identified in Lao PDR, Nam Xouang reservoir is only inhabited by 21 species. The biodiversity of fish in reservoirs is formed on the biodiversity of the original rivers, particularly the principal river system. However, after impoundment, there may be significant changes in fish fauna due to changes in the hydrological regime and biological conditions. There is a huge loss to our indigenous fish species due to constructions of dams that have severely affected migratory fishes. The frequent water level fluctuations in the reservoirs lead to deposition of silt and other suspended particles. The effects exist on biotic communities in the reservoirs. The most apparent impact of reservoirs is the permanent destruction of terrestrial ecosystems through inundation. Construction of reservoirs affects fish species diversity by sudden environmental changes from lotic to lentic. This changing due to which many species either escape to new conducive environments while few species get adapted to the changing environment [7].

Table 1. Nam Xouang Reservoir annual fish catch estimates for 2014 to 2017

\begin{tabular}{|c|c|c|c|c|}
\hline \multirow[b]{2}{*}{ Year } & Production (kgs) & Effort (unit) & & CPUE \\
\hline & \multicolumn{4}{|c|}{ Phonhong District } \\
\hline 2014 & 208,925 & & 5,264 & 39,689 \\
\hline 2015 & 216,506 & & 5,436 & 39,828 \\
\hline 2016 & 201,345 & & 5,092 & 39,541 \\
\hline \multirow[t]{2}{*}{2017} & 203,619 & & 5,047 & 40,345 \\
\hline & \multicolumn{4}{|c|}{ Naxaytong District } \\
\hline 2014 & 81,895 & & 12,749 & 6,424 \\
\hline 2015 & 81,479 & & 12,665 & 6,433 \\
\hline 2016 & 72,456 & & 11,222 & 6,457 \\
\hline 2017 & 63,156 & & 9,647 & 6,547 \\
\hline
\end{tabular}


Table 2 shows the list of the finding 21 species, and the enumerators informed that the dominants fish in each district are Oxyeleotris marmoratusin Naxaythong District while Osteochilus melanopleurus in Phonhong District. After that, Figure 2 shows the relationship between length and weight of two species from each district, those representatives for dominant and economic species.

Table 2. Fish inhabited in Nam Xouang Reservoir

\begin{tabular}{|c|c|c|c|}
\hline No. & Local Name & Common Name & Scientific Name \\
\hline 1. & Pa kheng & Climbing perch & Anabas testudineus (Bloch, 1792) \\
\hline 2. & Pa douk & Philippine catfish & Clarias batrachus (Linnaeus, 1758) \\
\hline 3. & Pa khor & Striped snakehead & Channa striata (Bloch, 1793) \\
\hline 4. & Pa khorjon & & Channa Lucius (Cuvier, 1831) \\
\hline 5. & Pa do & Indonesian snakehead & Channa micropeltes (Cuvier, 1831) \\
\hline 6. & Pa dokgiew & & Cyclocheilichthys armatus (Valenciennes, 1842) \\
\hline 7. & Pa soodyai & Hampala barb & Hampala macrolepidota (Kuhl \& Van Hasselt, 1823) \\
\hline 8. & Pa soodnoi & & Hampala dispar (Smith, 1934) \\
\hline 9. & Pa kotleuang & & Hemibagrus filamentus (Fang \&Chaux, 1949) \\
\hline 10. & Pa lot & Peacock eel & Macrognathus siamensis (Günther, 1861) \\
\hline 11. & Ian & Asian swamp eel & Monopterusalbus (Zuiew, 1793) \\
\hline 12. & Pa kot & Asian redtail catfish & Mystus nemurus (Valenciennes, 1840) \\
\hline 13. & Pa tong & Bronze featherback & Notopterus notopterus (Pallas, 1769) \\
\hline 14. & Pa nin & Nile tilapia & Oreochromis niloticus (Linnaeus, 1758) \\
\hline 15. & Pa nikkhao & & Osteochilus melanopleurus (Bleeker, 1852) \\
\hline 16. & Pa bou & Marble goby & Oxyeleotris marmoratus (Bleeker, 1852) \\
\hline 17. & Pa suay & & Pangasius krempfi (Fang \&Chaux, 1949) \\
\hline 18. & Pa ka & Malayan leaffish & Pristolepis fasciata (Bleeker, 1851) \\
\hline 19. & Pa khao mon & & Puntius brevis (Bleeker, 1849) \\
\hline 20. & Pa kadert & Three spot gourami & Trichopodus trichopterus (Pallas, 1770) \\
\hline 21. & Pa salid & Snakeskin gourami & Trichopodus pectoralis (Regan 1910) \\
\hline
\end{tabular}

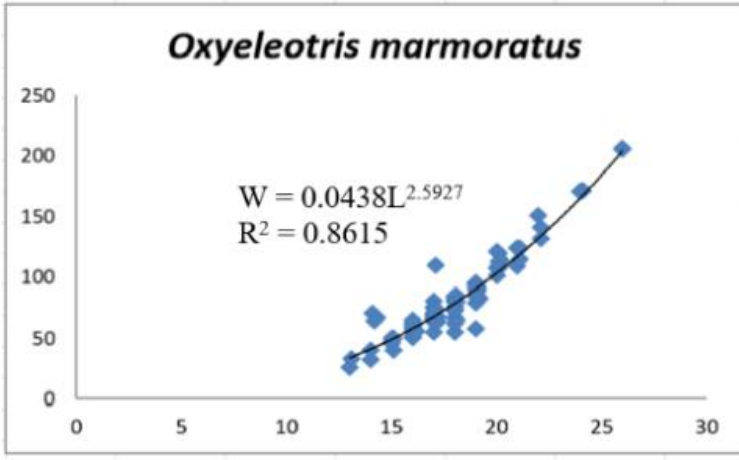

(a)

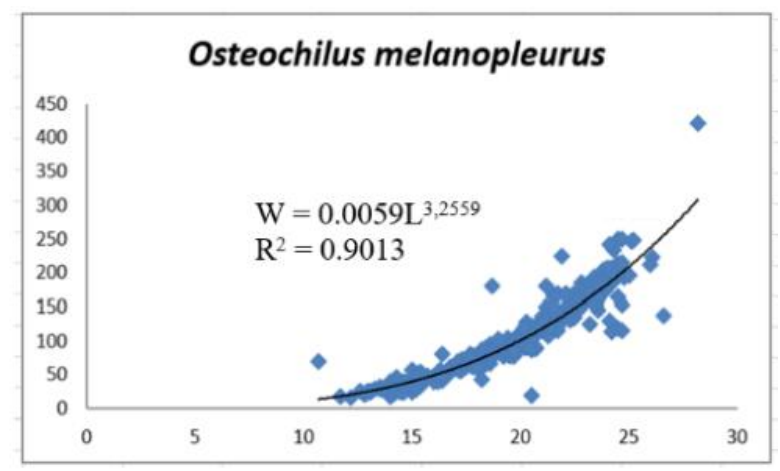

(b)

Figure 2. Length-weight relationship of selected fish in Nam Xouang Reservoir,

(a) Naxaythong District; (b) Phonhong District

The length-weight relationship is useful to estimate the condition of fish in different water bodies or during different seasons [8] [9]. The valid b values should range from 2.5 to 3.5 [10]. However, the $\mathrm{b}$ value ranged from 2.5927 and 3.2559 for both of fish in this study that it might be due to the influence of water quality or food availability on fish growth [11]. The relationship data presented provide a basic knowledge on these species which can be used in further studies. It can help to improve the information needed to derive at proper management measures.

The local fishers of Nam Xouang reservoir commonly use almost the same types of fishing gear for both the dry and wet seasons. Most of the local fishers mainly use gillnet, long line, set hook and line, and others (Figure 3). 


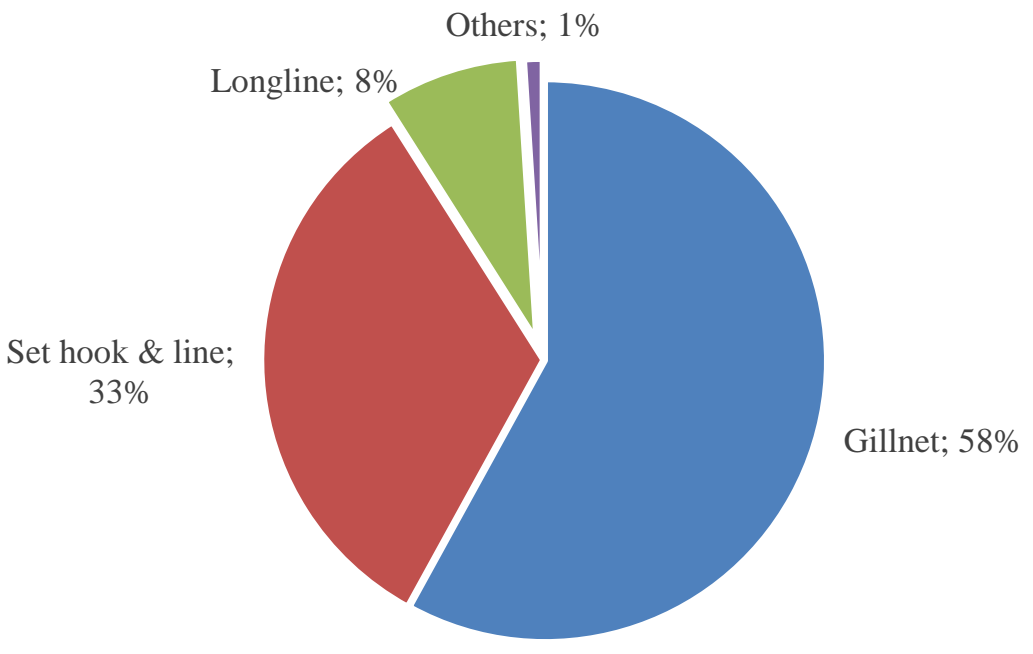

Figure 3. Percentage of used fishing gears at Nam Xouang reservoir

During the present study recorded that the enumerators used the gill-net, usually a very selective fishing gear. Some fishing methods and gear types may impact on the fisheries and the environment. Different mesh sizes ranging from 3 inches to 9 inches were observed in the gill nets used. As passive gear, gill net catches the migration of fish through the area where the nets are set, and the operculum of fishes get entangled into the meshes of nets when the fishes try to pass through it. Depending upon mesh size, the size of the fish caught for this was usually 250 grams to $10 \mathrm{~kg}$. The fishes are occasionally caught up to $20-30 \mathrm{~kg}$ or even more size fishes. The fishing methods vary from catching with hands to the operation of large and designed nets for fishing. Various types of fishing gears were reported operating in the fisheries sector and have increased the fish caught [12] [13].

\subsection{Establish the Conservation Zone}

There are five conservation zones in Nam Xouang Reservoir, where four areas served for the close season. The main activities of FMC include: monthly meeting, rule, and regulation on fisheries, define the fisheries conservation zone, patrolling in the conservation area, fish releasing, training and transfer knowledge and information to the community, and revolving fund [14]. The main problems found in the area are illegal fishing, theft of fishing gear, lack of knowledge on fisheries law, and regulation as well as unclear the conservation area.

The recent study selected Nam Xouang Reservoir to be the pilot site due to no project implementation and the lack of knowledge on fisheries law for fishers and regulation as well as the co-management. The study summarized the main issue found in Nam Xouang Reservoir is the management of the conservation zone. The preliminary meetings were held to strengthen and unify the rules and regulations of Phonhong and Naxaythong Districts as part of the management plan. This activity was conducted to build the same perception of developing habitat conservation. After having the same opinion on habitat conservation, the meeting was organized to install the buoys for demarcation of the conservation zone. The area was plotting and mapping as the fish habitat conservation. The pointed zone is based on the preliminary study that concerned on fish identification, fish composition, and fish growth. Thereafter, the FMC identified the spawning ground and feeding ground from vegetation grows in the waters, and waters always inundate the areas. For determining the nursery grounds, the FMC choose the area depending on two criteria, i.e., 1) the density of juveniles was higher than in other areas, and 2) repeatedly used over the years. Twenty-eight buoys with marking were installed to let the local fishers and residents knowing about the conservation areas.

On the last survey, the signboards for conservation zone demarcation are set upand the ceremony was organized to inform the local fishers on rules. The ceremony was attended and welcomed by Director of Deputy General of Fishery Division and the Major of each district. Some regulations were set up near the reservoir. The habitat conservation developed particularly built behind the temple because residents and tourists respect the Monks who are keeping the zones. Figure 4 shows the decided area for the habitat conservation, which the area appointed because the FMC had declared to not allowed the fishing activity in the areas in order to enhance new recruitment of the fish stock. The fishing regulation signboards in Nam Xouang Reservoir, Lao PDR were installed in eight villages of two districts hence it held the awareness creation on fisheries co-management including the community rule and regulations. The signboards are to promote 
the responsible on utilization on inland fisheries activity and mentioned for the Regulation for Fisheries Management of Fisheries Community
Zone. This regulation does not allow personal and the group of the people use any fishing gears and other animal aquatic in this whole zone.

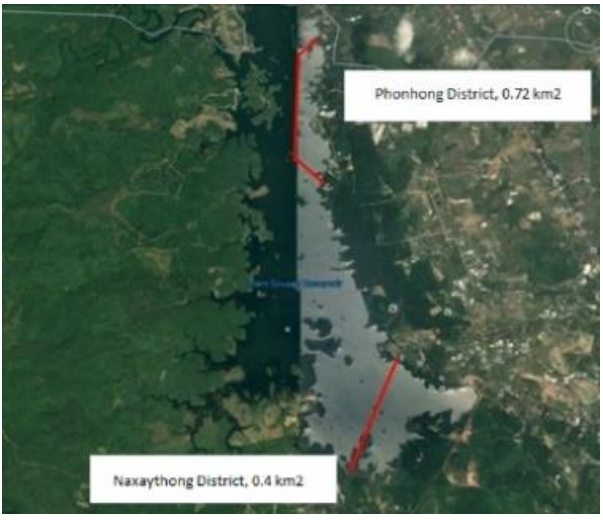

(a)

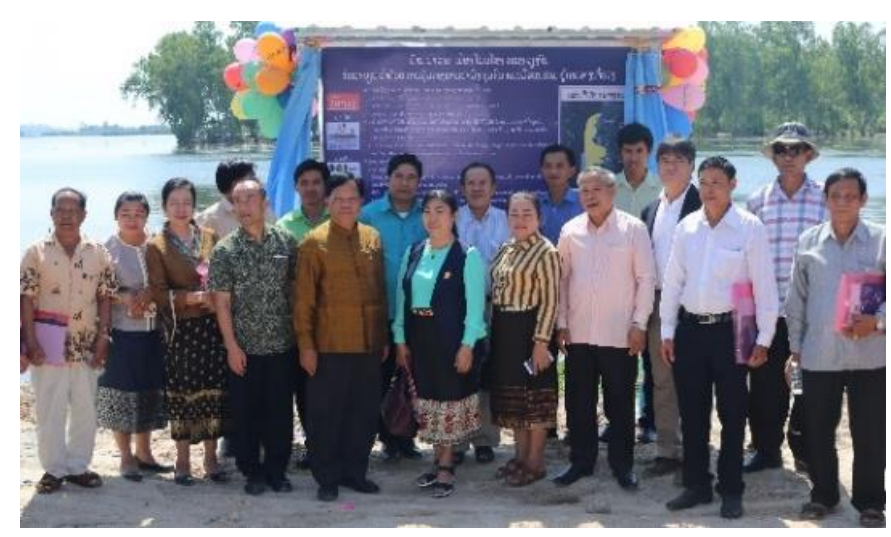

(b)

Figure 4. (a) Decided of demarcation for conservation zone in Nam Xouang Reservoir;

(b) The signboards installed near Nam Xouang Reservoir.

\section{Conclussion}

The gill-net caught the migration of fish which through the area of this gear set up. The lengthweight relationship from the fish caught is useful to estimate the condition of fish in different water bodies or during different seasons, due to the influence of water quality or food availability on fish growth. It can help to improve the information needed to derive at proper management measures.

The building of both display boards and warning signs is an effective way to consider simultaneously, to inform the local villagers about the fishing regulations and fish conservation zones by influencing on compliance issues, awareness-raising campaigns, and behavior enforcement. The participation of local fishing communities and local authorities might be necessary for the successful and sustainable management of the fisheries in the Nam Xouang Reservoir.

\section{Acknowledgment}

This paper is part of the contribution to research on "Promotion of responsible utilization of inland fisheries in Southeast Asia" in 2018, funded by Japan Trust Fund VI. The authors gratefully acknowledge for Prof. Dr. Ngurah N. Wiadnyana to read and gave the comments for the paper draft, and Mr. Freddy Supriyadi to prepare the map. We also thank Fisheries Division staffs of Department of Livestock and Fisheries Lao PDR, and researchers for SEAFDEC/Training Department for good collaboration and invaluable help during the field survey.

\section{References}

[1] Phonvisay, S. 2013. An introduction to the Fisheries of Lao PDR. Mekong Development
Series No. 6, 62 pages. Mekong River Commission, Phnom Penh, Cambodia. ISSN 1680-4023.

[2] Phounsavath, S. 2015. Promoting Comanagement in Inland Fisheries: Experience of Lao PDR. Fish for the People. SEAFDEC. Bangkok. Volume 13 Number 3. p33-40.

[3] Lao People's Democratic Republic. 2009. Fisheries Law: National Assembly No. 03/NA 2009. Vientiane Capital, July, 09, 2009.

[4] R.L. Welcomme and D.M. Bartley. 1998. An evaluation of present techniques for the enhancement of fisheries. Petr. T. (ed.) Inland fishery enhancements. Papers presented at the FAO/DFID Expert Consultation on Inland Fishery Enhancements. Dhaka, Bangladesh, 7$11 \quad$ April 1997. FAO Fisheries Technical Paper. No. 374. Rome, FAO. 1998. 463p.

[5] Gulland, J.A. 1983. Fish stock assessment A manual of basic methods. FAO/Wiley Ser. on Food and Agriculture, Vol 1: 233 pp.

[5] Chuan Ng, C.K., Abdullah, F., Biun, H., Ibrahim, M.F., Mustapha, S. and Sade, A. 2017. Review: A working checklist of the freshwater fish diversity for habitat management and conservation work in Sabah, Malaysia, North Borneo. Biodiversitas. ISSN: 1412-033X. Volume 18, Number 2, April 2017 E-ISSN: 2085-4722. Pages: 560-574.

[7] Sarkar, U.K. J. Sharma, and B.K. Mahapatra. 2015. A Review on the Fish Communities in the Indian Reservoirs and Enhancement of Fisheries and Aquatic Environment. Journal of Aquaculture Research and Development 6:1.

[8] Goncalves, J.M.S., Bentes, L., Lino, P.G., Ribeiro, J., Canário, A.V.M., and Erzini, K. 
1997. Weight-length relationships for selected fish species of the small-scale demersal fisheries of the south and south-west coast of Portugal. Fisheries Research, 30, 253-256.

[9] Petrakis, G., and Stergiou, K. I. 1995. Weightlength relationships for 33 fish species in Greek waters. Fisheries Research, 21, 465-469.

[10] Froese, R. 2006. Cube law, condition factor and weight-length relation-ship: History, metaanalysis and recommendations. Journal of Applied Ichthyology, 22, 241-253.

[11] Mommsen, T. P. 1998. Growth and metabolism. In D. H. Evans (Ed.), The physiology of fishes (pp. 65-97). New York: CRC Press.
[12] Hameed MS, and John AT. 1996. Types of fishing craft and gear operating in Indian waters. Fishing Chaims. 15(11):36-39.

[13] Saxena, RK. 1988. Fishing methods in river Systems. In: Conservation and Management of Inland Capture Fisheries Resources of India. (Eds). Jhingran AG, Sugunan VV. Inland Fisheries Society of India.CIFRI, Barrackpore, West Bengal. p61-68.

[14] Phounsavath, S. 2014. Development of Fisheries Co-management in Lao PDR: Past Experiences and Future Perspectives: Paper presented during the Experts Meeting on Mekong Cooperation on Fisheries, Aquatic Resources and Wetlands: 20year Lessons Learnt, 12-14 November 2014, Phnom Penh, Cambodia. 